\title{
Building wood debris piles benefits avian seed dispersers in burned and logged Mediterranean pine forests
}

\author{
Josep Rost $^{1}$, Miguel Clavero ${ }^{1,2}$, Josep M. Bas $^{1}$, Pere Pons ${ }^{1}$
}

1. Departament de Ciències Ambientals, Universitat de Girona, Campus de Montilivi, 17071 Girona, Catalonia, Spain.

2. Grup d'Ecologia del Paisatge, Àrea de Biodiversitat, Centre Tecnològic Forestal de Catalunya. Carretera vella de Sant Llorenç de Morunys, km 2. 25280 Solsona, Catalonia, Spain.

\begin{abstract}
Salvage logging is a common practice carried out in burned forests worldwide, and intended to mitigate the economic losses caused by wildfires. Logging implies an additional disturbance occurring shortly after fire, although its ecological effects can be somewhat mitigated by leaving wood debris on site. The composition of the bird community and its capacity to provide ecosystem services such as seed dispersal of fleshy-fruited plants have been shown to be affected by postfire logging. We assessed the effects of the habitat structure resulting from different postfire management practices on the bird community, in three burned pine forests in Catalonia (western Mediterranean). For this purpose, we focused on the group of species that is responsible for seed dispersal, a process which takes place primarily during the winter in the Mediterranean basin. In addition, we assessed microhabitat selection by seed disperser birds in such environments in relation to management practices. Our results showed a significant, positive relationship between the density of wood debris piles and the abundance of seed disperser birds. Furthermore, such piles were the preferred microhabitat of these species. This reveals an important effect of forest management on seed disperser birds, which is likely to affect the dynamics of bird-dependent seed dispersal. Thus, building wood debris piles can be a useful practice for the conservation of both the species and their ecosystem services, while also being compatible with timber harvesting.
\end{abstract}

Keywords: salvage logging, postfire management, winter bird community, frugivorous birds, seed dispersal, Pinus halepensis.

\section{Introduction}

Wildfires are one of the most important disturbances affecting ecological processes and economic interests in forest ecosystems worldwide (Blondel \& Aronson 1999, Hessburg 
\& Agee 2003, FAO 2007). In many countries postfire salvage logging (i.e., the harvesting of burned timber for mainly commercial purposes) is the most extended forestry practice intended to compensate for the economic losses caused by wildfires (Hutto 2006; Lindenmayer et al. 2004). Salvage logging is also justified by other objectives, such as reducing the fuel load, enhancing future tree survival, preventing the proliferation of xylophagous insects or making it easier and safer for people to pass through the burned area or for future forest management work to be carried out (Ne’eman et al. 1995, Martínez-Sánchez et al. 1999, Lindenmayer \& Noss 2006).

In the Mediterranean Basin, where there has been a long history of landscape management, fires often take place in lowland pine forests, most of which grow on abandoned agricultural land (Trabaud 1981). In this type of forest, after a fire, salvage logging is the most frequently used management method, because pine wood is still commercially profitable for use as boards until two years after a fire, and even later if ground down (e.g., to produce biomass fuel). In general terms, salvage logging involves a drastic habitat change - from a burned forest structure to open grassland and shrubland - a short time after the fire. However, on a smaller scale the characteristics of these new open habitats also depend on the interests and decisions of landowners and managers, and therefore on the ownership structure of each burned forest. When forests are divided into small privately-owned lots, as is often the case in Mediterranean areas, individual decisions lead to the coexistence of multiple management models in burned stands in close proximity. These strategies result in clearcuts (where wood debris may be completely removed, left on the ground or piled up), areas where isolated snags remain, and unlogged stands of partially burned pines. Furthermore, restoration measures such as log erosion barriers can be found in burned public forests, which are managed essentially for restoration purposes. The administrative authority concerned may also issue management recommendations, and grant subsidies to, or reach agreements with, local landowners, who may then delegate postfire management to public managers.

The habitat disturbance induced by postfire salvage logging affects animal communities, an issue that has sometimes been studied using birds as the focal group (Kotliar et al. 2002, Hutto \& Gallo 2006, Cahall \& Hayes 2009). It has been shown that salvage logging can have a greater impact than the fire itself on the forest bird community, including the substitution of forest specialists by open-land species (Izhaki 1993, Llimona et al. 1993, Morisette et al. 2002, Castro et al. 2010). Such changes are likely to affect frugivorous bird species, some of which are involved in important ecological processes such as seed dispersal of fleshy-fruited shrubs and climbers. In the Mediterranean, fleshy-fruited plants produce ripe fruit during the fall and winter (Mooney \& Kummerow 1981, Jordano 1992), when various species of small and medium-sized birds disperse their seeds (Herrera 1984, Herrera 1998). In burned areas, early succession gives rise to a shrubland-like habitat (Trabaud \& Lepart 1980), which hosts a diverse winter bird assemblage, including some species that attain high densities thanks to postfire fruit and seed production (Pons \& Prodon 1996, Pons 2001, Tellería 
et al. 2004). Izhaki \& Adar (1997) showed that winter bird communities in eastern Mediterranean burned and logged forests were dominated by shrubland species, some of which were seed dispersers. However, the habitat and microhabitat use of these species under different scenarios of postfire management has not yet been studied in depth. Previous studies have reported that bird-dependent seed rain strongly relies on habitat structures that act as dispersal foci, such as isolated trees that act as perches (Guevara \& Laborde, 1993; Pausas et al. 2006, Herrera \& García 2009). After logging, wood debris piles and barriers built in a burned pine forest can also act as dispersal foci (Rost et al. 2009). Thus, the variability of postfire treatments after logging, which leads to the presence of different microhabitats on a small scale, may have important implications for bird-dependent seed rain, depending on the differential use that seed dispersers make of the resulting microhabitats.

The aims of this study are: (1) to investigate the effects of postfire management on winter bird communities in burned Mediterranean pine forests, (2) to determine whether certain management practices have positive effects on species richness and abundance of seed dispersers in winter, and (3) to analyze microhabitat selection by seed dispersers in order to describe patterns in their use of the microhabitats. If postfire management practices had an effect on seed dispersers distribution and microhabitat use, this would also affect seed rain and the regeneration of fleshy fruit-producing shrub or climber species. We took advantage of the availability in three study areas of examples of different postfire logging practices (ranging from completely logged areas to unlogged ones, and including different methods of managing wood debris) to investigate which of these practices may be more favorable to the presence of bird species involved in seed dispersal.

\section{Methods}

\section{Study area}

The study was carried out in three burned areas located in Catalonia, in the northeast of the Iberian Peninsula: Torroella de Montgrí (henceforth TM, 3ㄱ' E, 42³' N), Ventalló $\left(\mathrm{VE}, 3^{\circ} 2^{\prime} \mathrm{E}, 42^{\circ} 7^{\prime} \mathrm{N}\right)$ and Cistella (CI, $\left.2^{\circ} 50^{\prime} \mathrm{E}, 42^{\circ} 17^{\prime} \mathrm{N}\right)$ (Figure 1). The maximum distance between any two areas was $30 \mathrm{~km}$. All three areas have a meso-Mediterranean climate, limestone substrates, and altitudes ranging from 80 to $210 \mathrm{~m}$ above sea level. Before the fire, they featured a vegetation mosaic composed of Aleppo pine (Pinus halepensis) forests, shrubland and crops. TM burned in September 2004 and the fire affected 188 ha of pine forest; in VE and CI fires burned 613 and 170 ha of pine forest, respectively, in August 2006. All were severe fires that affected forest canopy and undergrowth, and as a result the vast majority of pines died and the shrub cover disappeared. 


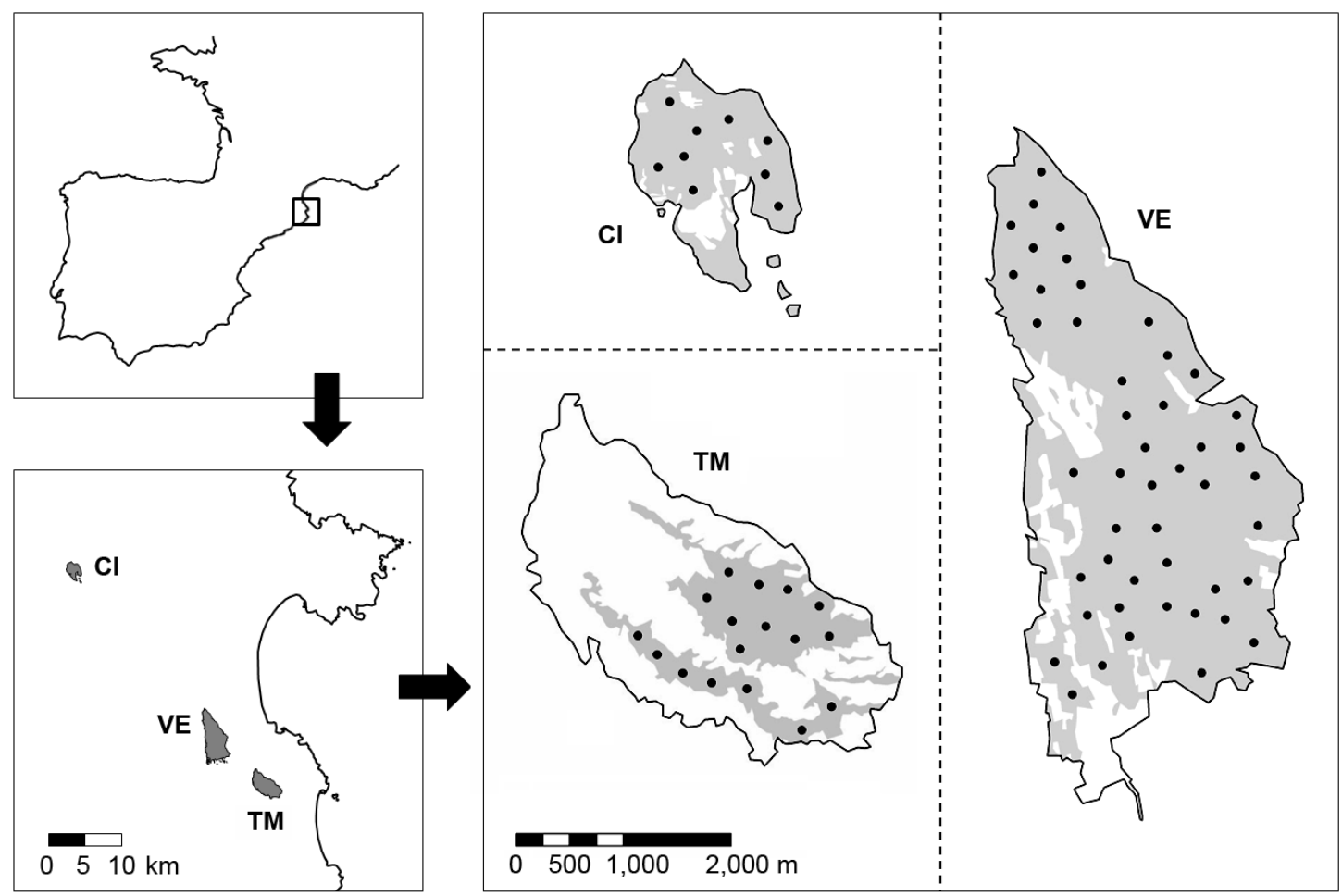

Figure 1. Location of the three study areas and distribution of the 76 stations (dots) within these areas (CI: Cistella; TM: Torroella de Montgrí; VE: Ventalló). Gray areas correspond to the former forests zones on which the study focused. Fire perimeters obtained from DMAH (2008).

Properties at VE and CI study areas are small and privately owned. In VE 96\% of the area is in private ownership, with stands ranging in area from 0.5 to 5 ha and only a few stands larger than 15 ha, while in CI $100 \%$ of the area is in private ownership, with one stand of 80 ha and the rest ranging from 5 to 20 ha. In both areas salvage logging started during the first winter after the fires and was still happening when the fieldwork was conducted, affecting approximately $60 \%$ of the burned forest area in VE and about $75 \%$ in CI. The few forest patches where pines survived after the fires were left unlogged. In a few areas, non-profitable wood debris was heaped up in small, low piles. In TM, the predominance of public ownership (66\% of the total area) led to patchy postfire management, including both logged and unlogged areas and restoration measures. In logged patches, however, a few standing snags were preserved (ca. 10 snags/ha) and log barriers were built up against runoff and erosion by piling trunks and branches along the contour lines (the sizes of the piles being 0.5-1 m high and 3-10 m long) (Rost et al., 2009). By the time we conducted the fieldwork in TM all unlogged snags had fallen down, as had almost a third of those in VE and CI.

The study was conducted in winter 2008-09, the third winter after the fires in VE and CI and the fifth in the case of TM, when vegetation was in early succession. The regenerating undergrowth was composed of resprouter and seeder shrubs (Quercus coccifera, Phillyrea angustifolia, Cistus spp.) and herbs (Brachypodium spp.), with young Aleppo pine saplings in many stands. We concentrated all fieldwork in a single 
month (January) in order to avoid as much as possible the changes in bird abundance that may happen along winter.

\section{Bird sampling}

We distributed 74 sampling stations of $100 \mathrm{~m}$ radius in the study areas, following a regular spatial distribution within the burned forests (48 stations in VE, 17 in TM and 9 in CI; Figure 1). When choosing the exact location of the stations we bore in mind to allow a minimum distance between station centers $(300 \mathrm{~m})$, to ensure good visibility, and to sample a homogeneous habitat (burned forest with the same management model). Recently logged areas (less than four weeks after logging) were not sampled in order to avoid the disturbance that logging work might have caused to the birds. Birds were counted using the point count method (Bibby et al. 1992) once at each station. All counts were performed by the same observer, conducted between one and four hours after dawn and under good weather conditions. All birds seen or heard within a $100 \mathrm{~m}$ radius during three consecutive five-minute periods were registered, but individuals seen just flying over were not counted, as they were not considered to be using the sampled habitat. In order to reduce the probability of double counts during the 15 minutes, we computed each species' abundance as the maximum number of individuals in any of the three five-minute periods. We initially separated bird observations in three distance bands from the observer $(0-25 \mathrm{~m}, 25-50 \mathrm{~m}$ and $50-100 \mathrm{~m})$ to account for detectability. However, the estimation of detection probabilities with Distance 5 program (Thomas et al. 2006) was only possible for the $42 \%$ most frequent species. For these species, bird density taking into account detection probability was highly correlated with the raw abundance $\left(\mathrm{R}^{2}=0.83\right)$. Moreover, at least $67 \%$ of detections of the species that accounted for $75 \%$ of the total abundance where auditory, so that birds were detected rather irrespectively of the cover structure. For these reasons we used raw abundances in all the analyses.

\section{Habitat variables}

Habitat variables related to vegetation recovery and postfire management were recorded at each station. Within a $20 \mathrm{~m}$ radius area centered on the station we estimated the relative area (in percentage) covered by: bare ground, vegetation up to $0.25 \mathrm{~m}$, vegetation up to $0.5 \mathrm{~m}$, vegetation up to $1 \mathrm{~m}$, and vegetation higher than $1 \mathrm{~m}$ (excluding live trees), which all together totaled $100 \%$. The density and cover of standing snags and live trees were measured in a $20 \mathrm{~m}$ radius area (if density was $>100$ trees/ha), $50 \mathrm{~m}$ radius area (between 10 and 100 trees/ha) or $100 \mathrm{~m}$ radius area (<10 trees/ha). The density (number/ha) and cover of wood debris piles or barriers in a $50 \mathrm{~m}$ radius area, and the cover of logging debris scattered on the ground in a $20 \mathrm{~m}$ radius area were considered as management variables. Cover measures were estimated by visual 
comparison with the template used by Prodon \& Lebreton (1981), except for scattered wood debris, for which we designed a specific template (Figure 2).

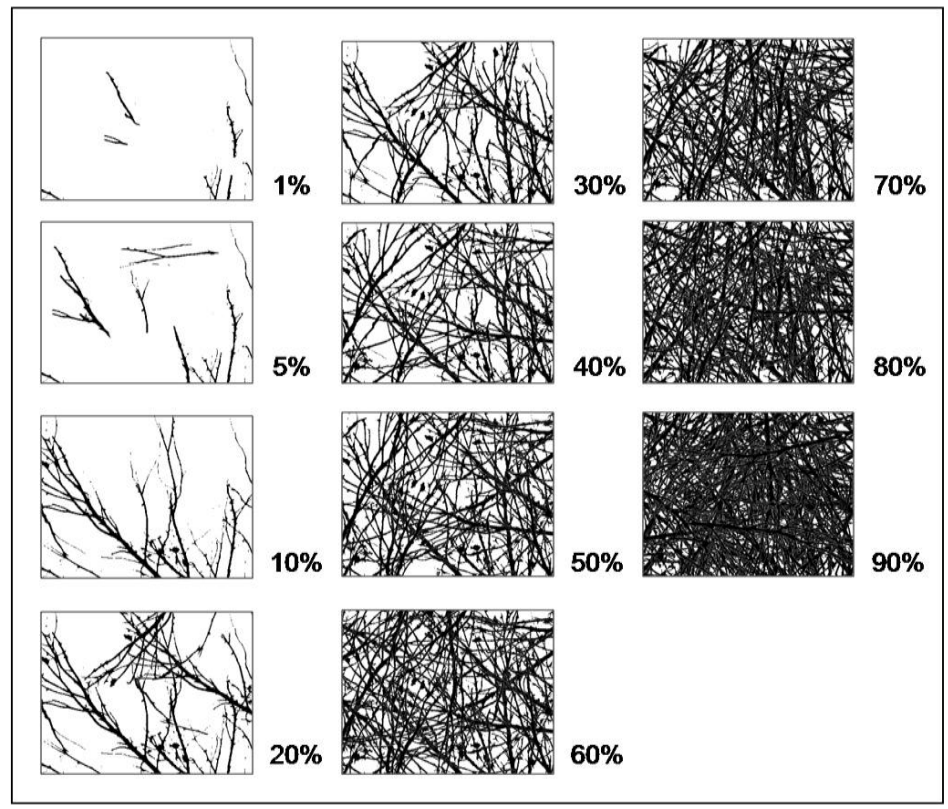

Figure 2. Template used to estimate the scattered wood debris cover on the ground.

\section{Microhabitat selection by avian seed dispersers}

As a result of the postfire management explained above, we defined five different microhabitat categories: live trees, standing snags, regenerated shrubs, wood debris piles, and bare ground. The availability of each microhabitat was estimated as its cover (in percentage) within the station. During point counts, we recorded the microhabitat, (only one in each case) in which individual birds were detected. For flushed out individuals, we recorded the microhabitat from which they had flown away. When this was not possible (e.g., in the case of wood piles among live shrubs and bare ground patches), the second site where the bird stopped was recorded, since the first movement might have been influenced by the presence of the observer. The behavior of seed disperser species of fleshy-fruited plants was also recorded, categorized as foraging, perching, sheltering or unknown (when a bird had been flushed out and not relocated). Only those species classified as major dispersers in Herrera (1995), that is, all species of the genus Sylvia and Turdus plus the European robin (Erithacus rubecula), were considered as seed dispersers in the analyses.

\section{Data analyses}

Multivariate analyses were used to explore the relationships between bird community and habitat structure. All species occurring in less than 5\% of point counts were excluded. A redundancy analysis (RDA) was applied to the species and to the habitat and management variables matrices, including burned area as a covariate. A forward 
selection of habitat variables was performed using Monte-Carlo permutation tests and including those variables that were significant at a $p<0.1$ level. In the RDA, two species occurring in $3-5 \%$ of the points were included as supplementary species (thus not influencing the analysis results). These were the European jay (Garrulus glandarius), because of its importance as oak acorns disperser, and the Southern grey shrike (Lanius meridionalis), because of the interest in its conservation in Europe (BirdLife International 2004). We used a linear method (RDA) instead of a unimodal approach because the length of the gradient of a DCA performed to the 20 species and 74 samples matrix was 2.75 SD, suggesting a mostly linear response of the species (ter Braak \& Smilauer 1998). RDA and DCA were performed with CANOCO (ter Braak \& Smilauer 1998). A Principal Components Analysis (PCA) with varimax rotation was performed to resume habitat variability in a reduced number of habitat gradients. The variables used were bare ground, all the live vegetation categories defined above, snag density, and live tree density. We interpreted the meaning of principal components using variables with factor loadings higher than 0.6 , in absolute value. PCA gradients were kept to be used as predictor variables in subsequent analyses. We used Statistica 6 (Statsoft Inc. 2001) to perform this analysis.

Generalized linear mixed models (GLMM) were used to assess the importance of habitat-management variables on the following community variables: abundance and species richness of the overall bird community, and abundance and species richness of seed dispersers. Abundances of most common seed dispersers were also analyzed. We used first two PCA gradients, scattered wood debris cover and piles density as predictors. GLMM with Poisson error and link log were performed, including the locality as a random factor in order to control possible site-based differences. For each dependent variable, the minimum adequate model was selected following a manual backward selection procedure, retaining those predictors with p-values smaller than 0.05. GLMMs were performed with program R 2.9.2 ( $\mathrm{R}$ Development Core Team 2009), using the lme4 software.

Microhabitat selection by seed disperser birds was analyzed for the overall seed dispersers group and for the three most abundant seed disperser species (Sardinian warbler [Sylvia melanocephala], Dartford warbler [Sylvia undata] and European robin) by comparing observed and expected bird observation frequencies in each microhabitat with chi-square tests. Expected frequencies were calculated from the availability of microhabitats in the stations where the species had been detected, after scaling these microhabitats' cover to 1. Behavior was not included in the analyses due to the excessive reduction of frequencies that would be involved by doing so, and was only represented graphically. 


\section{Results}

In the point counts we recorded a total of 744 birds belonging to 38 species (Table 1). The most abundant species were the Sardinian warbler, the Dartford warbler, the European robin, the Hedge accentor (Prunella modularis) and the Chaffinch (Fringilla coelebs). The seed disperser group is composed by nine species (Table 1), which accounted for $58 \%$ of the total abundance, the three most abundant accounting for $48 \%$ of the total abundance.

RDA results showed that habitat variables explained $16 \%$ of the total variance of the species dataset, and the first two axes explained $87 \%$ of the species-environment relationships (eigenvalues: first axis $=0.08$, second axis $=0.04$ ). Covariates explained an additional $9 \%$ of the variance. The ordination of species along these two axes shows two main gradients, one related to regenerated vegetation structure and the other related to the density of snags and live trees (i.e., the logging intensity) (Figure 3). The first gradient separates species that require open areas with low vegetation cover, such as the Woodlark (Lullula arborea), from those that dwell in well-developed, high shrubland, such as the Sardinian warbler and the Blackcap. The second axis separates forest species that prefer high tree density, such as Parus tits or Chaffinches, from those that mainly select unwooded habitats in winter, which is the case of the Dartford warbler, the European robin or the Zitting cisticola (Cisticola juncidis).

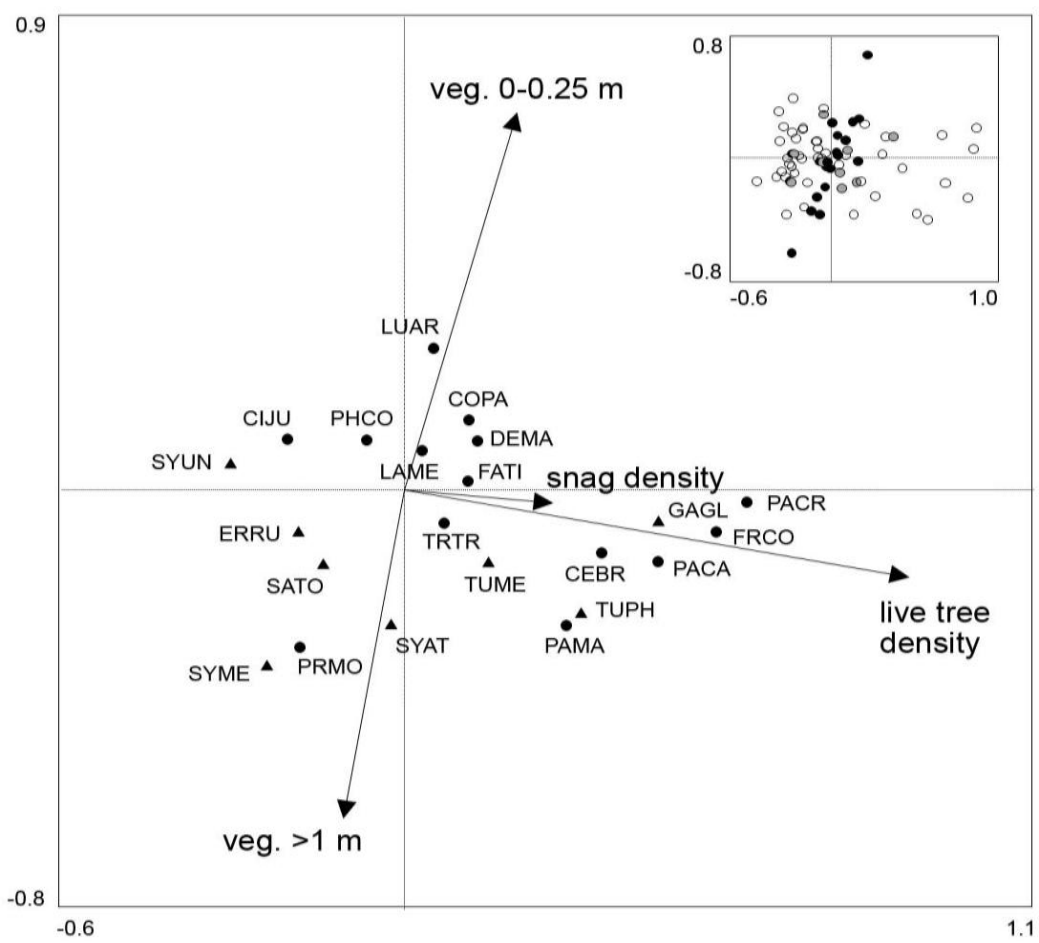

Figure 3. Biplot of the first two axes of the RDA, showing species and significant environmental variables (live vegetation up to $0.25 \mathrm{~m}$, live vegetation higher than $1 \mathrm{~m}$, snag density and live tree density). Triangle marks indicate seed disperser species. Species abbreviations are shown in Table 1. The inset graph (top left) shows the ordination of samples along the same axes, with dots representing the study areas (black-TM; gray-CI and white-VE). 
Table 1. Species recorded in all 74 point counts with occurrence and total number of individuals. Asterisks show seed disperser species (Herrera 1984) of fleshy-fruit plants, and double asterisks show major disperser species (Herrera 1995). The horizontal bar separates those species considered in multivariate analyses from those not considered.

\begin{tabular}{|c|c|c|c|c|}
\hline English name & Scientific name & Acronym & Occurrence & Sum of counts \\
\hline Sardinian warbler $* *$ & Sylvia melanocephala & SYME & 71 & 191 \\
\hline Dartford warbler $* *$ & Sylvia undata & SYUN & 52 & 93 \\
\hline European robin $* *$ & Erithacus rubecula & ERRU & 48 & 74 \\
\hline Hedge accentor & Prunella modularis & PRMO & 33 & 44 \\
\hline Winter wren & Troglodytes troglodytes & TRTR & 26 & 29 \\
\hline Chaffinch & Fringilla coelebs & FRCO & 24 & 43 \\
\hline Great tit & Parus major & PAMA & 20 & 30 \\
\hline Chiffchaff & Phylloscopus collybita & $\mathrm{PHCO}$ & 16 & 16 \\
\hline Woodlark & Lullula arborea & LUAR & 15 & 24 \\
\hline Song thrush $* *$ & Turdus philomelos & TUPH & 13 & 28 \\
\hline Blackcap ** & Sylvia atricapilla & SYAT & 12 & 19 \\
\hline Blue tit & Parus caeruleus & PACA & 12 & 17 \\
\hline Blackbird $* *$ & Turdus merula & TUME & 11 & 14 \\
\hline Zitting cisticola & Cisticola juncidis & CIJU & 10 & 12 \\
\hline Crested tit & Parus cristatus & PACR & 8 & 10 \\
\hline Short-toed treecreeper & Certhia brachydactyla & CEBR & 8 & 11 \\
\hline Great Spotted woodpecker & Dendrocopos major & DEMA & 6 & 6 \\
\hline Stonechat $*$ & Saxicola torquata & SATO & 6 & 7 \\
\hline Common kestrel & Falco tinnunculus & FATI & 4 & 4 \\
\hline Woodpigeon & Columba palumbus & COPA & 4 & 12 \\
\hline European jay $*$ & Garrulus glandarius & GAGL & 3 & 4 \\
\hline Common buzzard & Buteo buteo & BUBU & 2 & 2 \\
\hline Meadow pipit & Anthus pratensis & ANPR & 2 & 2 \\
\hline Long-tailed tit & Aegithalos caudatus & AECA & 2 & 5 \\
\hline Southern grey shrike & Lanius meridionalis & LAME & 2 & 2 \\
\hline Goldfinch & Carduelis carduelis & CACD & 2 & 6 \\
\hline Serin & Serinus serinus & SESE & 2 & 11 \\
\hline Cirl bunting & Emberiza cirlus & EMCI & 2 & 2 \\
\hline Peregrine falcon & Falco peregrinus & FAPE & 1 & 1 \\
\hline Hoopoe & Upupa epops & UPEP & 1 & 1 \\
\hline Green woodpecker & Picus viridis & PIVI & 1 & 1 \\
\hline Alpine accentor & Prunella collaris & PRCO & 1 & 3 \\
\hline Blue rock-thrush & Monticola solitarius & MOSO & 1 & 1 \\
\hline Mistle thrush ** & Turdus viscivorus & TUVI & 1 & 1 \\
\hline Greenfinch & Carduelis chloris & $\mathrm{CACH}$ & 1 & 2 \\
\hline Linnet & Carduelis cannabina & $\mathrm{CACN}$ & 1 & 1 \\
\hline Red crossbill & Loxia curvirostra & LOCU & 1 & 2 \\
\hline Corn bunting & Miliaria calandra & MICA & 1 & 13 \\
\hline
\end{tabular}

The first axis of the PCA explained 29\% of total variance in habitat characteristics (eigenvalue $=2.04$ ), and was positively related to vegetation up to $1 \mathrm{~m}$ and higher than $1 \mathrm{~m}$, and negatively to bare ground and vegetation up to $0.25 \mathrm{~m}$. The second axis explained a further $21 \%$ of the variance (eigenvalue $=1.50$ ), and was positively related to snag density and vegetation up to $0.5 \mathrm{~m}$. The first factor thus represented undergrowth structures ranging from open areas to high shrublands, while the second ordered samples from clearcuts to areas with high snag density. 
The overall bird abundance was higher in areas of low density of snags and live trees, while overall richness was not affected by any habitat-management predictor. The abundance of seed dispersers was positively related to pile density and shrub cover and negatively to snag density, and their species richness was not affected by any predictor. Shrub cover was also related to the abundance of the Sardinian warbler, the most common seed disperser. In addition to influence frugivores abundance, pile density favored the occurrence of the Dartford warbler, the European robin, and the Blackcap (Sylvia atricapilla). On the other hand, Turdus thrushes did not show any habitatmanagement preferences. See Table 2 for further details and significance values.

Both the seed disperser group and the three most abundant species (Sardinian warbler, Dartford warbler and European robin) used available habitat elements in a non-random fashion (Figure 5). As a group, seed dispersers were most frequently found on piles, resprouting shrubland and snags, using piles and snags more than would be expected from habitat element availability $\left(\chi^{2}=643.16, p<0.01\right)$. In terms of individual species, the Sardinian Warbler, Dartford Warbler and European Robin prefered wood piles more than expected $\left(\chi^{2}=258.14, \quad \mathrm{p}<0.01 ; \chi^{2}=100.03, \mathrm{p}<0.01\right.$, and $\chi^{2}=173.10, \mathrm{p}<0.01$, respectively). Behavior observations revealed that bird species used these elements for somewhat different purposes, with Sardinian and Dartford warblers using piles and shrubs basically for foraging, and European robins mostly for perching.

\section{Discussion}

Habitat heterogeneity in burned Mediterranean pine forests allows the coexistence of bird species with different habitat requirements during winter, and thus we found a mixture of open land, shrubland and forest birds in our study sites. Such habitat and bird community heterogeneity likely results from the management carried out in these areas, as well as from the regeneration of the low plant cover. We found that different management practices favored different bird species in winter. Indeed, managers decisions, such as the extent of snag logging and how wood debris is managed, that depend both on their objectives (harvest/restoration) and on the small size of lots in the area, greatly affect which bird species will occupy the area. Thus, strict open land birds may take profit both from fire, which creates open areas of low herbs and bare ground, and from logging, because of the mechanical damage to ligneous vegetation associated with logging operations, which hinders proper regeneration (Martínez-Sánchez et al. 1999, van Nieuwstadt et al. 2001, Lindenmayer \& Noss, 2006). Shrubland birds dwell in the regenerated shrubs and bushes that have grown since fire and logging occurred, as well as in newly-built wood piles and barriers. In these clearcuts created by salvage logging, winter bird abundance is higher than in unlogged patches where snags have been retained. However, unlogged areas allow the persistence of some forest species that do not occur when snags are logged. 
Table 2. Summary of GLMM selected models analyzing the effect of habitat and management variables (PCA1, PCA2, pile density and scattered wood debris cover) on the overall community abundance and richness, major disperser abundance and richness and most common major disperser species abundance, using locality as a random factor. Explained variance is shown as the variation in deviance between null and selected models, when both differed.

\begin{tabular}{lllll}
\hline Response variable & Explained variance (\%) & Predictors & Estimate & $p$ \\
\hline
\end{tabular}

Overall community

\begin{tabular}{lcrrr}
\hline Abundance & 4.3 & PCA2 & -0.090 & 0.016 \\
Richness & 0.0 & - & - & \\
& & & & \\
Major seed dispersers & & Pile density & 0.009 & 0.017 \\
\hline Abundance & 5.3 & PCA1 & 0.141 & 0.005 \\
& & PCA2 & -0.116 & 0.030 \\
Richness & & Pile density & 0.009 & 0.088 \\
Sardinian warbler & 9.6 & PCA1 & 0.200 & 0.006 \\
Dartford warbler & 10.8 & Pile density & 0.016 & 0.026 \\
European robin & 4.7 & Pile density & 0.023 & 0.003 \\
Blackcap & 6.2 & Pile density & 0.042 & 0.003 \\
Blackbird & 15.0 & - & - & - \\
Song thrush & 0.0 & - & - & - \\
\hline
\end{tabular}
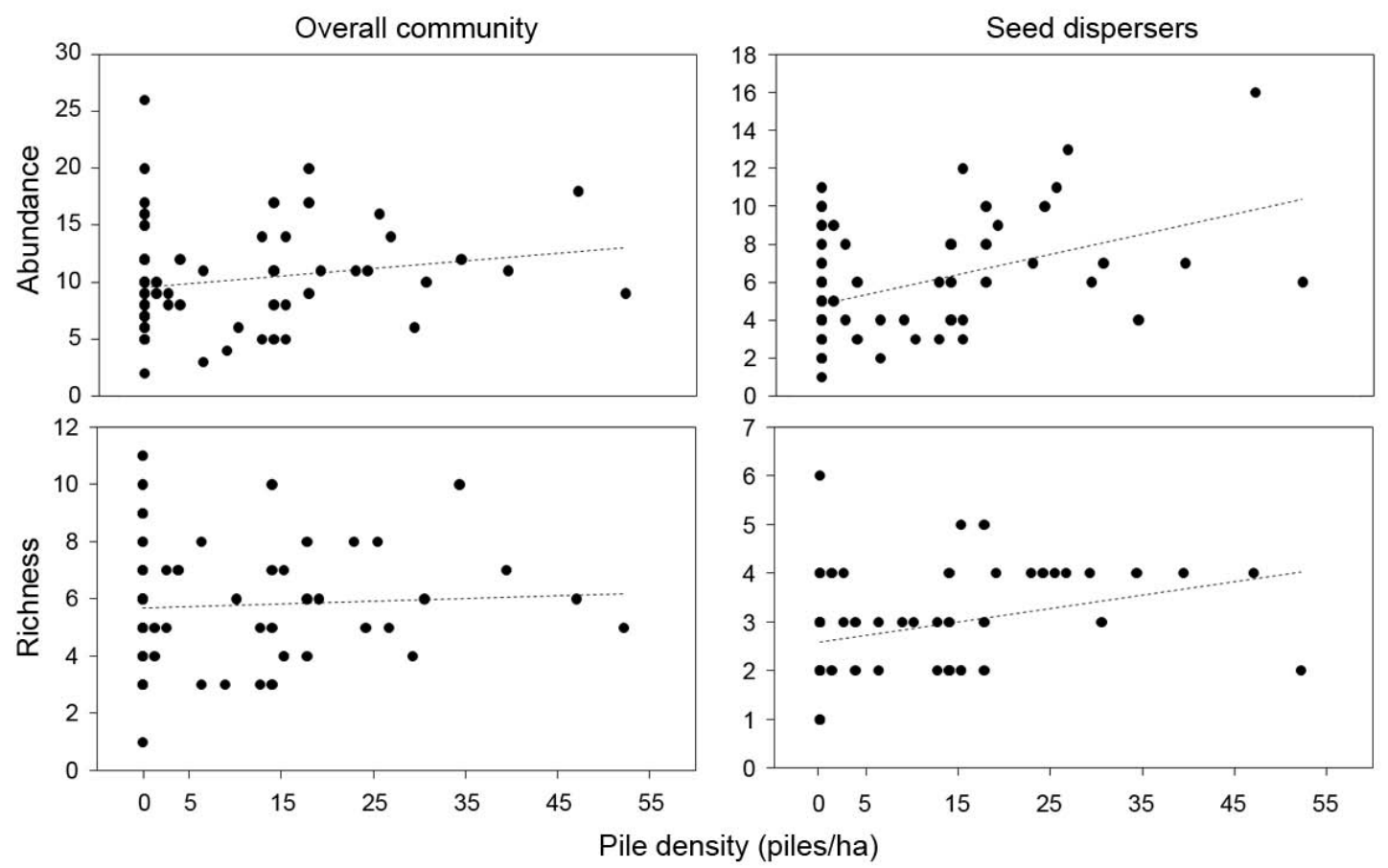

Figure 4. Effect of pile density on overall community and seed dispersers abundance and species richness. Only major seed dispersers have been considered (Herrera 1995). The dashed line represents the linear regression line.

Almost a quarter of all bird species and more than half of the individuals detected in the study area were seed dispersers, and among them, the Sardinian and Dartford warblers and the European robin were the most frequent species. In general, Sylvia warblers occurred mainly in bushy habitats without snags and trees. However, they showed some 


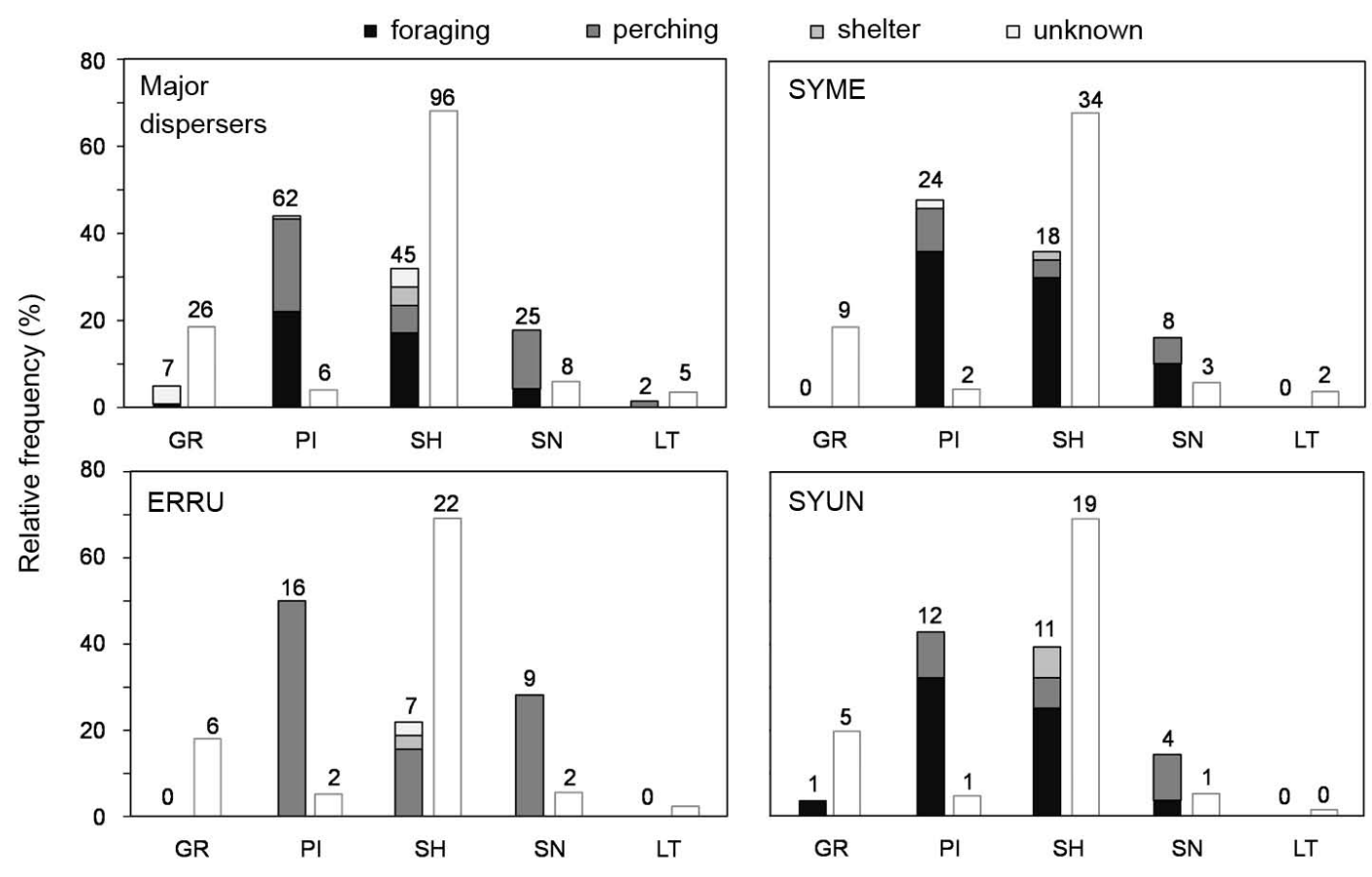

Figure 5. Relative frequencies of microhabitat use by all major disperser species, the Sardinian warbler (SYME), the European robin (ERRU) and the Dartford warbler (SYUN). For each habitat element (GR, ground; PI, pile; SH, shrub; SN, snag; LT, living tree), the left bar shows observed frequencies for four behavior categories, while the right white bar shows expected frequencies (for every graph, observed and expected frequencies add up 100\%). The numbers above the bars show the number of observed or expected frequencies for each category.

differences in habitat preferences in accordance with their requirements (Shirihai et al. 2001), because Dartford warblers were found in lower shrubland than Sardinian warblers and Blackcaps. The European robin was found in similar habitats to those of warblers, since wintering individuals can occur in more open and drier habitats than breeding ones (Snow \& Perrins 1998). On the other hand, Turdus thrushes were not closely linked to any specific habitat, but the Song thrush seemed more related to the presence of snags and live trees. By contrast, Castro et al. (2010) found that in Mediterranean montane pine forests, Turdus thrushes were the most abundant seeddisperser/frugivorous species in winter, the European robin was absent, and Sylvia warblers were uncommon. Salvage logging can thus have different effects on the seed dispersers group depending on the altitude, probably being more detrimental for seed dispersers in montane than in lowland forests.

The most remarkable result of our study is that seed dispersers are more abundant where piles of burned wood are built up in large quantities, being particularly important for Dartford warblers, European robins and Blackcaps. The vertical structure of these piles or barriers may give them the appearance of shrub patches and thus attract birds in early successional vegetation stages (Herrando et al. 2009), and seemed also to be important structures for species such as the European robin that are used to perching frequently when foraging, or as part of their territorial behavior. Furthermore, the occurrence of macro-arthropods in coarse wood debris (Grove 2002, Jabin et al. 2004, Varady-Szabo 
\& Buddle 2006) may increase the use of piles by insectivorous species. In addition, the preference for piles shown by frugivorous birds may have interesting ecological implications for the seed rain process in burned and managed areas, and support the role played by piles as seed dispersal foci (Rost et al. 2009). If dispersed seeds can germinate and survive under piles, a positive relationship between the abundance of fleshy-fruited plants and of frugivorous birds is likely, since piles may later host a greater abundance of such plants, and thus become important feeding points for frugivorous birds. However, the possible link between piles and fruit availability is a subject still to be studied. Apart from this, another way to deal with wood debris is to leave it scattered on the ground. Our results show that this management method did not have a big effect on the frugivorous guild.

Building wood debris piles in burned and logged areas may therefore be an important factor for fleshy-fruited plants, if afterwards these structures become points of high densities of dispersed and established plants. This could lead to a heterogeneous distribution of dispersed plant species within burned logged areas where piles have been built up. Seed disperser birds can bring seeds from unburned neighboring areas, where they may have eaten fruit, into burned areas (Rost et al. 2009). The arrival of migrant frugivores and the loss of territorial behavior of local ones during winter could allow longer dispersal distances than in spring-summer, when seed dispersal by birds takes place only at short distances (i.e., mostly below 100 meters) (Jordano et al. 2006). Therefore, birds attracted to burned areas by the presence of wood debris piles could facilitate the colonization of these areas by the dispersed plant species, with possible positive consequences for the recovery of the vegetation after fire.

The implications, suggested here, of the effect of management practices on seed disperser birds and on the seed dispersal process, are also likely to apply to forests altered by other harvesting practices. Common forest management measures in the Mediterranean, such as undergrowth clearing and tree thinning, intended to produce open forest stands for pasture, to maximize timber production or to reduce the risk of fire by eliminating the fuel load, are likely to cause such changes. Some existing studies of these management techniques and bird communities in the Mediterranean region (Camprodon \& Brotons 2006, De La Montaña et al. 2006) found that some major seed dispersers (Sardinian warbler, Blackcap, Garden warbler Sylvia borin and Blackbird) disappear or decline locally when shrub clearing and thinning occur. This may mean a disruption in the seed dispersal process in such managed areas because of the lack of dispersers, negatively affecting bird-dispersed plant species. In such situations, piling up cut branches and other woody debris could therefore be seen as palliative measures, because they may provide shrubland-dwelling seed disperser birds with some resources that may favor their site tenacity. 


\section{Management recommendations}

Our results suggest that the abundance and distribution of bird species in burned lowland pine forests in the western Mediterranean during the winter is strongly influenced by the implementation of postfire forest management practices. As shown in our results, if managers and landowners decide to harvest the burned pines, the fate of wood debris (branches and non-profitable logs) is not a trivial issue for birds, because it affects the abundance of major seed disperser species. Our recommendation, since scattered wood debris has no effect on birds abundance, is to collect and heap it up in piles of at least $0.5 \mathrm{~m}$ high. Around $15-25$ piles/ha could be an appropriate density to allow the persistence of seed disperser birds in winter. Furthermore, wood piles, if found in an appropriate density, also have a positive effect on the species richness and abundance of breeding bird species (Herrando et al. 2009), on the abundance of some species of rodents (Haim \& Izhaki 1994, Manning \& Edge 2008), and even on the European rabbit (Catalán et al. 2008, Joan Real pers. comm.), a keystone of Mediterranean ecosystems. In most cases, the main purpose of building up wood debris piles is to reduce soil loss by erosion (Robichaud et al. 2000), although it is not clear that they are useful for that purpose (Raftoyannis \& Spanos 1998, Marquès \& Mora 1998). Nevertheless, their value for birds and other fauna would justify their inclusion in postfire management plans aiming to restore the habitat or introduce environmentally-friendly measures. Such practices seem feasible in public pine forests where postfire management is not so closely linked to economic imperatives, and could be made a requirement to obtain public subsidies for the management of private forests. Including the building up of wood debris piles in postfire management guidelines could thus become an important factor in helping to conserve both species and animaldependent ecological services in the Mediterranean region. Finally, dialogue with landowners of burned forests is a necessary step to find ways to make economic objectives compatible with the benefits of biodiversity, thus facilitating the maintenance of important ecological functions such as bird-dependent seed dispersal processes.

\section{Acknowledgements}

The authors would like to thank David Meya and Joan Real for kindly providing us with advice and information. This study was funded by the Spanish Ministry of Science and Innovation (CGL2005-0031/BOS and CGL2008-05506/BOS) and J.R. held a FPU grant of the Ministry of Education.

\section{References}

Bibby, C.J., Burgess, N.D. \& Hill, D.A. 1992. Bird census techniques. Cambridge University Press, Cambridge. 
BirdLife International. 2004. Birds in Europe: population estimates, trends and conservation status. BirdLife Conservation Series No. 12. BirdLife International, Wageningen.

Blondel, J. \& Aronson, J. 1999. Biology and Wildlife of the Mediterranean Region. Oxford University Press, New York.

ter Braak, C. J. F. \& Smilauer, P. 1998. CANOCO reference manual and User's Guide to Canoco for Windows. Software for Canonical Community Ordination (Version 4). Microcomputer Power, Ithaca, New York.

Cahall, R.E. \& Hayes, J.P. 2009. Influences of postfire salvage logging on forest birds in the Eastern Cascades, Oregon, USA. Forest Ecology and Management 257, 1119-1128.

Camprodon, J., \& Brotons, L. 2006. Effects of undergrowth clearing on the bird communities of the Northwestern Mediterranean Coppice Holm oak forests. Forest Ecology and Management 221, 72 82.

Castro, J., Moreno-Rueda, G. \& Hódar, J.H. 2010. Experimental test of post-fire management in pine forests: impact of salvage logging versus partial cutting and non-intervention on bird-species assemblages, Conservation Biology 24, 810-819.

Catalán, I., Rodríguez-Hidalgo, P. \& Tortosa F.S. 2008. Is habitat management an effective tool for wild rabbit (Oryctolagus cuniculus) population reinforcement? European Journal of Wildlife Research $54,449-453$.

De La Montaña, E., Rey-Benayas, J.M. \& Carrascal, L.M. 2006. Response of bird communities to silvicultural thinning of Mediterranean maquis. Journal of Applied Ecology 43, 651-659.

DMAH (Departament de Medi Ambient i Habitatge, Generalitat de Catalunya). 2008. Incendis 1986-2008 - Medi Ambient i Habitatge. http://mediambient.gencat.cat.

FAO. 2007. State of the World's Forests 2007. FAO, Rome.

Grove, S.J. 2002. Saproxylic insect ecology and the sustainable management of forests. Annual Review of Ecology, Evolution and Systematics 33, 1-23.

Guevara, S. \& Laborde, J., 1993. Monitoring seed dispersal at isolated standing trees in tropical pastures -consequences for local species availability. Vegetatio 108, 319-338

Haim, A. \& Izhaki, I. 1994. Changes in rodent community during recovery from fire: relevance to conservation. Biodiversity and Conservation 3, 573-585.

Herrando, S., Brotons, L., Guallar, S., Sales, S. \& Pons, P. 2009. Postfire forest management and Mediterranean birds: the importance of logging remnants. Biodiversity and Conservation 18, 2153-2164.

Herrera, C.M. 1984. A study of avian frugivores, bird-dispersed plants, and their interaction in Mediterranean scrublands. Ecological Monographs 54, 1-23.

Herrera, C.M. 1995. Plant-vertebrate dispersal systems in the Mediterranean: Ecological, Evolutionary and Historical Determinants. Annual Review of Ecology, Evolution and Systematics 26, 705-726.

Herrera, C.M. 1998. Long-term dynamics of Mediterranean frugivorous birds and fleshy fruits: a 12-year study. Ecological Monographs 68, 511-538.

Herrera, J.M. \& García, D., 2009. The role of remnant trees in seed dispersal through the matrix: being alone is not always so sad. Biological Conservation 142, 149-158.

Hessburg, P.F. \& Agee, J.K. 2003. An environmental narrative of Inland Northwest United States forests, 1800-2000. Forest Ecology and Management 178, 23-59.

Hutto, R.L. 2006. Toward Meaningful Snag-Management Guidelines for Postfire Salvage Logging in North American Conifer Forests. Conservation Biology 20, 984-993. 
Hutto, R.L. \& Gallo, S.M. 2006. The effects of postfire salvage logging on cavity-nesting birds. The Condor 108, 817-831.

Izhaki, I. 1993. The resilience to fire of passerine birds in an East-Mediterranean pine forest on Mount Carmel, Israel: the effects of postfire management. In: Trabaud, L. \& Prodon, R. (eds.). Fire in Mediterranean Ecosystems. Ecosystems Research Report, 5. Commission of the European Communities, Bruxelles. Pp. 303-314.

Izhaki, I. \& Adar, M. 1997. The effects of postfire management on bird community succession. International Journal of Wildland Fire 7, 335-342.

Jabin, M., Mohr, D., Kappes, H. \& Topp, W. 2004. Influence of deadwood on density of soil macroarthropods in a managed oak-beech forest. Forest Ecology and Management 194, 61-69.

Jordano, P. 1992. Fruits and frugivory. In: Fenner, M. (ed.). Seeds. The Ecology of Regeneration in Plant Communities. C.A.B. International, Wallingford. Pp. 125-166.

Jordano, P., García, C., Godoy, J.A. \& García-Castaño, J.L. 2006. Differential contribution of frugivores to complex seed dispersal patterns. Proceedings of the National Academy of Sciences 104, 32783282.

Kotliar, N.B., Hejl, S.J, Hutto, R.L., Saab, V., Melcher, C.P. \& McFadzen, M.E. 2002. Effects of fire and postfire salvage logging on avian communities in conifer-dominated forests of the western United States. In: George, T.L. \& Dobkin, D.S. (eds.). Effects of habitat fragmentation on birds in western landscapes: contrasts with paradigms from the eastern United States. Studies in Avian Biology No. 25. Cooper Ornithological Society, Camarillo. Pp. 49-64.

Lindenmayer, D.B., Foster, D.R., Franklin, J.F., Hunter, M.L., Noss, R.F., Schmiegelow, F.A. \& Perry, D. 2004. Salvage harvesting policies after natural disturbance. Science 303, 1303.

Lindenmayer, D.B. \& Noss, R.F. 2006. Salvage Logging, Ecosystem Processes and Biodiversity Conservation. Conservation Biology 20, 949-958.

Llimona, F., Matheu, E. \& Prodon, R. 1993. Role of snag persistence and of tree regeneration in postfire bird successions: comparison of pine and oak forests in Montserrat (Catalonia, NE Spain). In Trabaud, L. and Prodon, R. (eds.). Fire in Mediterranean Ecosystems. Ecosystems Research Report, 5. Commission of the European Communities, Bruxelles. Pp. 315-331.

Manning, J.A. \& Edge, W.D. 2008. Small mammal responses to fine woody debris and forest fuel reduction in southwest Oregon. Journal of Wildlife Management 72, 625-632.

Marquès, M.A. \& Mora, E. 1998. Effects on erosion of two postfire management practices: clearcutting versus non-intervention. Soil \& Tillage Research 45, 433-439.

Martínez-Sánchez, J.J., Ferrandis, P., de las Heras, J. \& Herranz, J.M. 1999. Effect of burnt wood removal on the natural regeneration of Pinus halepensis after fire in a pine forest in Tus valley (SE Spain). Forest Ecology and Management 123, 1-10.

Mooney, R.E. \& Kummerow, J. 1981. Phenological development of plants in mediterranean-climate regions. In: Di Castri, F., Goodall, D.W. \& Specht, R.L. (eds.), Ecosystems of the World 11. Mediterranean Type Shrublands. Elsevier, Amsterdam. Pp. 303-307.

Morisette, J.L., Cobb, T.P., Brigham, R.M. \& James, P.C. 2002. The response of boreal songbird communities to fire and postfire harvesting. Canadian Journal of Forest Research 32, 2169-2183.

Ne'eman, G., Lahav, H. \& Izhaki, I. 1995. Recovery of vegetation in a natural east Mediterranean pine forest on Mount Carmel, Israel as affected by management strategies. Forest Ecology and Management 75, 17-26.

Pausas, J.G., Bonet, A., Maestre, F.T. \& Climent, A., 2006. The role of the perch effect on the nucleation process in Mediterranean semi-arid oldfields. Acta Oecologica 29, 346-352. 
Pons, P. 2001. The wintering of migrant Dunnocks Prunella modularis in two Mediterranean habitats after fire. Bird Study 48, 68-75.

Pons, P. \& Prodon, R. 1996. Short term temporal patterns in a Mediterranean shrubland bird community after fire. Acta Oecologica 17: 29-41.

Prodon, R. \& Lebreton, J. D. 1981. Breeding avifauna of a Mediterranean succession: the holm oak and cork oak series in the eastern Pyrenees, 1. Analysis and modelling of the structure gradient. Oikos 37, 21-38.

R Development Core Team. 2009. R: A language and environment for statistical computing. R Foundation for Statistical Computing, Vienna.

Raftoyannis, Y. \& Spanos, I. 2005. Evaluation of $\log$ and branch barriers as postfire rehabilitation treatments in a Mediterranean pine forest in Greece. International Journal of Wildland Fire 14, $183-188$.

Robichaud, P.R., Beyers, J.L. \& Neary, D.G. 2000. Evaluating the effectiveness of postfire rehabilitation treatments. USDA Forest Service, Fort Collins.

Rost, J., Pons, P. \& Bas, J.M. 2009. Can salvage logging affect seed dispersal by birds into burned forests? Acta Oecologica 35, 763-768.

Shirihai, H., Gargallo, G. \& Helbig, A., 2001. Sylvia warblers: identification, taxonomy and phylogeny of the genus Sylvia. Helm, London.

Snow, D. \& Perrins, C. (eds.). 1998. The complete Birds of the Western Palearctic on CD-ROM. Oxford University Press, Oxford.

StatSoft, Inc. 2001. STATISTICA for Windows [Computer program manual]. StatSoft, Inc., Tulsa.

Tellería, J.L., Ramírez, A. \& Pérez-Tris, J. 2004. Conservation of seed-dispersing migrant birds in Mediterranean habitats: Shedding light on patterns to preserve processes. Biological Conservation 124, 493-502.

Thomas, L., Laake, J.L., Strindberg, S., Marques, F.F.C., Buckland, S.T., Borchers, D.L., Anderson, D.R., Burnham, K.P., Hedley, S.L., Pollard, J.H., Bishop, J.R.B. \& Marques, T.A. 2006. Distance 5.0. Release 2. Research Unit for Wildlife Population Assessment, St. Andrews.

Trabaud, L. 1981. Man and fire: impacts on Mediterranean vegetation. In: di Castri, F., Goodall, D.W., Pecht, R.L. (eds). Mediterranean-type shrublands. Ecosystems of the world 11. Elsevier, Amsterdam. Pp. 523-537.

Trabaud, L. \& Lepart, J., 1980. Diversity and stability in garrigue ecosystems after fire. Vegetatio 43, 4957.

Van Nieuwstadt, M.G., Shiel, D. \& Kartawinata, K. 2001. The ecological consequences of logging in the burned forests of east Kalimantan, Indonesia. Conservation Biology 15, 1183-1186.

Varady-Szabo, H. \& Buddle, C.M. 2006. On the relationships between ground-dwelling spider (Araneae) assemblages and dead wood in a northern sugar maple forest. Biodiversity and Conservation 15, 4119-4141. 